\title{
Host Abundance and Identity Determine the Epidemiology and Evolution of a Generalist Plant Virus in a Wild Ecosystem
}

\author{
Cristina Rodríguez-Nevado, ${ }^{1}$ Rosario G. Gavilán, ${ }^{2}$ and Israel Pagán ${ }^{1, \dagger}$ \\ ${ }^{1}$ Centro de Biotecnología y Genómica de Plantas UPM-INIA and E.T.S. Ingeniería Agronómica, Alimentaria y de Biosistemas, Departamento \\ de Biotecnología-Biología Vegetal, Universidad Politécnica de Madrid, Madrid, Spain \\ ${ }^{2}$ Facultad de Farmacia, Departamento de Farmacología, Farmacognosia y Botánica, unidad de Botánica, Universidad Complutense de Madrid, \\ Madrid, Spain \\ Accepted for publication 3 October 2019.
}

\begin{abstract}
Increasing evidence indicates that in wild ecosystems plant viruses are important ecological agents, and with potential to jump into crops, but only recently have the diversity and population dynamics of wild plant viruses begun to be explored. Theory proposes that biotic factors (e.g., ecosystem biodiversity, host abundance, and host density) and climatic conditions would determine the epidemiology and evolution of wild plant viruses. However, these predictions seldom have been empirically tested. For 3 years, we analyzed the prevalence and genetic diversity of Potyvirus species in preserved riparian forests of Spain. Results indicated that potyviruses were always present in riparian forests, with a novel generalist potyvirus species provisionally named Iberian hop mosaic

ecosystem. The main predictors of IbHMV infection risk were host relative abundance and species richness. Virus prevalence and host relative abundance were the major factors determining the genetic diversity and selection pressures in the virus population. These observations support theoretical predictions assigning these ecological factors a key role in parasite epidemiology and evolution. Finally, our phylogenetic analysis indicated that the viral population was genetically structured according to host and location of origin, as expected if speciation is largely sympatric. Thus, this work contributes to characterizing viral diversity and provides novel information on the determinants of plant virus epidemiology and evolution in wild ecosystems.
\end{abstract} virus (IbHMV), explaining the largest fraction of infected plants. Focusing on this potyvirus, we analyzed the biotic and climatic factors affecting virus infection risk and population genetic diversity in its native
Keywords: Potyvirus, riparian forests, virus infection risk, virus evolution, virus ecology, host range, speciation
For more than a century, the study of any aspect of plant-virus interactions has been motivated by the agroeconomic impact of virus infections in crops (Lefeuvre et al. 2019; Pagán et al. 2016). Only recently have virologists paid attention to plant-virus interactions in wild ecosystems. These analyses have revealed that virus infections are common in wild plants, and virus diversity and identity appear to be different from those in crops (Bernardo et al. 2017; Roossinck 2012; Stobbe and Roossinck 2014). Thus, analyzing the ecology, epidemiology, and evolution of plant viruses in wild ecosystems is central to fully understanding plant-virus interactions (Lefeuvre et al. 2019; Pagán et al. 2016).

In wild ecosystems, plant viruses may be important ecological agents. Viral infections can drastically reduce the number of individuals in the host populations by decreasing the competitive and/or reproductive abilities of infected plants (Anderson et al. 2004; Malmstrom et al. 2005; Vijayan et al. 2017). In response to infection, wild plants evolve quantitative resistance and tolerance (Moreno-Pérez et al. 2014; Montes et al. 2019; Pagán et al. 2010), which suggests that viruses shape the genetic composition of the host population. Viruses that infect wild hosts may also be

†Corresponding author: I. Pagán; jesusisrael.pagan@upm.es

Funding: This work was supported by Career Integration grant PCIG11-GA-2012322100, Plan Nacional de I+D+i, from Ministerio de Economía y Competitividad, Spain grant BIO2016-79165-R, and Universidad Politécnica de Madrid grant PINV18-O4W6R9-94-YR130U.

*The $e$-Xtra logo stands for "electronic extra" and indicates that three supplementary figures and four supplementary tables are published online.

The author(s) declare no conflict of interest.

(c) 2020 The American Phytopathological Society important for agriculture because wild ecosystems are often adjacent to crop fields, and plant viruses can move across this agroecological interface (Alexander et al. 2014; Roossinck and García-Arenal 2015). Despite the importance of wild plant viruses, their epidemiology and evolution are underexplored (Pagán 2018; Pagán et al. 2016). Most work on this subject has focused on plant viruses that typically infect crops (Cooper and Jones 2006; Malmstrom and Alexander 2016; Sacristán et al. 2004). However, in wild ecosystems these viruses are not necessarily the most abundant. Agroecosystems are often dominated by annual plants, or managed as such, whereas wild ecosystems are abundant with long-lived perennial plants (Blanco et al. 2005), and viruses adapted to wild perennials may overcompete crop viruses (Roossinck 2015; Wren et al. 2006). In addition, human management of agroecosystems has a great impact on plant virus populations (Alexander et al. 2014; Pagán et al. 2012; Rodelo-Urrego et al. 2015), so that plant viruses native to wild ecosystems may have different population dynamics than those typical of crops. Consequently, the factors driving virus epidemiology and evolution might be different than those described for crop viruses (Fraile et al. 2017).

Infection generally occurs in the context of complex ecological systems and involves interactions between at least the virus and its hosts. Thus, ecological factors determining the population dynamics of these interactive partners may affect virus epidemiology (Elena et al. 2014; Jones 2009). Theoretical works aiming at predicting the conditions that increase or decrease parasite infection risk (reviewed by Johnson et al. 2015; Ostfeld and Keesing 2012), a framework that can also be applied to plant viruses, group ecological factors that influence infection risk into climatic and biotic. Temperature, relative humidity, rainfall, and edaphic factors have been proposed to mediate infection risk through effects on host physiology that weaken plant defenses, effects on vector population dynamics that promote parasite transmission, and effects on host 
availability (Garrett et al. 2006; Kennelly et al. 2012; McLeish et al. 2018). On the other hand, changes in the host ecology (e.g., host species richness, relative abundance, identity, and density) have been identified as the most common biotic determinants of infection risk (Anderson et al. 2004; Jones 2009; Pagán et al. 2016). In this context, ecosystem biodiversity (i.e., the number of species and genotypes present in a given ecosystem; Wilson 1992) has been proposed as a key determinant of infection risk (Keesing et al. 2006; Ostfeld and Keesing 2012). Two contrasting hypotheses relate these two factors. The amplification effect hypothesis predicts that species diversity (here, of plant species) will be positively correlated with parasite (here, virus) infection risk, because increasing plant species diversity will result in higher abundance of host species. Conversely, the dilution effect hypothesis posits that reduced plant species diversity increases the abundance of the most competent host species, increasing virus infection risk (Keesing et al. 2006; Ostfeld and Keesing 2012). Further developments of these theories proposed that which of the two effects prevails depends on factors other than the host species diversity or abundance, such as the identity of the plant species present in the ecosystem (Johnson et al. 2015; Randolph and Dobson 2012; Seabloom et al. 2013). For instance, the local abundance of longlived perennial hosts can increase parasite prevalence by serving as long-term sources of infection for susceptible individuals (Borer et al. 2010; Herms and Mattson 1992).

Empirical analyses on the role of ecological factors in the risk of viruses infecting wild plant populations are scarce and with contradictory results, with examples that support the amplification effect (Malmstrom et al. 2005), the dilution effect (Pagán et al. 2012; Rodelo-Urrego et al. 2013, 2015), or neither (Rodríguez-Nevado et al. 2017). These heterogeneous results have been attributed in part to differences in virus host range: generalist (wide host range) $v s$. specialist (narrow host range). The amplification effect would require a generalist parasite. Otherwise, higher plant species richness would rarely increase the number of host species and consequently infection risk. Conversely, the dilution effect would require a specialist parasite (McLeish et al. 2018; Pagán et al. 2012). Notably, most of these empirical analyses of the dilution and amplification effects were centered in a focal host, and they defined virus host range according to previously existing literature. This focus limits the interpretation of the association between virus infection risk and host range, and host ecology, because virus host range may differ according to the habitat's floristic composition (McLeish et al. 2017). Moreover, these studies overlooked the role of climatic factors on plant virus host range and infection risk (McLeish et al. 2018).

Ecological changes that affect infection risk may also result in genetic changes in the plant virus population. Theory that accommodates parasites in general (including plant viruses) proposed that larger population sizes (a general consequence of higher infection risk) would increase population genetic diversity (Ellegren and Galtier 2016). In addition, host biodiversity may also affect that of the parasite: Higher host genetic diversity may lead to greater polymorphisms for resistance and consequently to more polymorphisms for parasite virulence and higher genetic diversity in the parasite population (Agrawal and Lively 2010; Haldane 1949; Hamilton 1980). Host range may also modulate parasite population genetic diversity. A specialist parasite is expected to be highly adapted to the host, because its survival depends on it. Thus, most mutations would be deleterious for the parasite, and therefore higher genetic diversity would be largely the consequence of accumulating mutations with no effect on parasite fitness (i.e., neutral evolution) (Barrett et al. 2008; Burdon and Thrall 2008). On the other hand, generalist parasites cannot optimize their fitness in all hosts, which leaves room to generate beneficial mutations in the available host(s) (i.e., host adaptation) (Pagán et al. 2016). Hence, selection pressures for adaptation to different hosts would drive the evolution of a generalist parasite (Agrawal and Lively 2010; Brown and Tellier 2011). This adaptation process may lead to polymorphisms for host specificity, which are involved in the appearance of new parasite species or lineages (i.e., speciation events) (Barrett et al. 2008; Elena et al. 2011; McLeish et al. 2018). Using an analogy with free-living organisms (Mayr 1963), theory proposes two major modes of parasite speciation, which are associated with host adaptation: allopatric and sympatric (Huyse et al. 2005). Sympatric speciation would occur when parasites diversify and adapt to different niches within the same host species (e.g., using different cell types, establishing different seasonalities). In contrast, allopatric speciation involves parasite genetic diversification in different host species by jumps from a reservoir to a new host and further independent coevolution in each host (Kitchen et al. 2011). Although ecological factors that affect infection risk may also be important determinants of parasite evolution, this relationship and how it affects virus speciation has been seldom tested, particularly for plant-virus interactions in wild ecosystems (Rodelo-Urrego et al. 2015; Rodríguez-Nevado et al. 2017).

In this study, we focused on the riparian forests of Spain within the Iberian Peninsula. The continuous water availability of these forests results in rich and structurally complex plant communities of high ecological value (Stella et al. 2013). The riparian vegetation communities delay the speed of water in floods, protect the stability of adjacent lands, and enable the deposit of nutrients transported by water, thus increasing soil fertility. As a consequence, large parts of the remaining peninsular riparian forests are protected. Still, the lands of riparian influence are often used for orchards, pastures, and crops, such that cultivated lands can be found near protected areas (Virgós 2001). Thus, analyzing virus diversity and population dynamics in riparian forest, a subject currently underexplored, may be both of ecological interest and relevant to understanding virus epidemics in crops. We focused on species of the genus Potyvirus. Potyviruses, which represent about $30 \%$ of all known plant virus species, infect species from all major botanical families and are transmitted by aphids (King et al. 2012). Most virus species in this genus are major crop pathogens (Walsh and Jenner 2002), and some of them have been reported to infect wild plant species commonly found in Spain (Malpica et al. 2006; Pagán et al. 2010; RodríguezNevado et al. 2017). Together, these observations suggest that they may be important ecological agents in riparian forests, with potential to cause epidemics in crops.

Here, we analyze the prevalence of Potyvirus species in riparian forests of Spain, as a measure of infection risk, based on surveys done between 2013 and 2016. This analysis identified a new potyvirus that infects six species from five different botanical families typical of Spanish riparian forests within the Iberian Peninsula, provisionally named Iberian hop mosaic virus (IbHMV). We analyze the ecological factors affecting IbHMV prevalence and evolution, and we explore the potential of the virus for dispersing into crops by determining its prevalence in cultivated fields located nearby riparian forests where IbHMV is present.

\section{MATERIALS AND METHODS}

Field sampling. Five locations of riparian forest located in Spain were visited between the summer of 2013 and the spring of 2016. The locations were distributed across a transect of $250 \mathrm{~km}$ (north-south) in the center of Spain (Fig. 1 and Supplementary Table S1), within the Mediterranean biogeographic region (Gavilán et al. 2018). Because of the special climatic conditions adjacent to riverbeds, Spanish riparian forests are representative of the Atlantic climate patches embedded in the Mediterranean region. As a consequence, in these riparian forests lives vegetation typical of the Atlantic environments, along with the riparian vegetation of Mediterranean distribution (Stella et al. 2013). The monitored forests occupied from 30 to $50 \mathrm{~m}$ up to $300 \mathrm{~m}$ on both sides of the riverbed and over acidic soils ( $\mathrm{pH} 5.0$ to 5.5), generally with roads at the forest's limits. Importantly, the sampled locations flood only occasionally (never during the monitored period) and underwent 
little or no management. Indeed, vegetation of the five monitored locations was composed of plant communities typical of Spanish riparian forests (see Blanco et al. 2005 for a list of species), including deciduous trees such as poplars (Populus nigra), willows (Salix atrocinerea), ashes (Fraxinus angustifolia), and Pyrenean oak (Quercus pyrenaica) that conformed the canopy. Plant species typical of adjacent ecosystems (generally evergreen oak forests) were rarely found, and representatives of nearby crops were never observed in the monitored locations.

At each location, we defined a plot of $25 \times 25 \mathrm{~m}$, which was divided into a grid of $1 \times 3 \mathrm{~m}$. From each of these rectangles, leaves of one individual of the most abundant plant species (including herbaceous and nonherbaceous vegetation) were harvested. This sampling scheme allowed identifying the position of each sampled plant within the $25 \times 25 \mathrm{~m}$ plot and therefore estimating plant density as the inverse of the mean Euclidean nearest neighbor distance (McGarigal et al. 2009). We chose this measure because, unlike other measures of plant density such as individuals per square meter, it best reflected the proximity between individuals of the same species by accounting for the uneven distribution of individuals in the plot. A total of 200 samples were collected at each location and visit. Individuals representative of each collected sample were also harvested and inventoried in herbariums (available upon request), and their botanical family and species were determined. With this information, we calculated plant species richness (S) as the number of species at each location and visit and plant species relative abundance as the number of individuals of a given species divided by 200. Samplings were performed in summer, autumn, and spring. A total of 9,000 samples were collected in these surveys. At each location and visit we also calculated plant biovolume in the plot (in cubic meters), which has been shown to be the best proxy of biomass for Iberian vegetation (Castro et al. 1996). To do so, at each location and visit, eight quadrants of $1 \mathrm{~m}^{2}$ were randomly selected and photographed, and these photographs were used to calculate the coverage of living plants in Image J version 1.5 (Schneider et al. 2012). Tree coverage was considered when present. Also, in the eight quadrants the maximum height of living plants was measured at three points across the diagonal of the quadrant. Values of plant coverage and height were used to calculate the biovolume by averaging values in the eight quadrants. We also collected from nearby weather stations information on minimal, maximal, and average temperature (in ${ }^{\circ} \mathrm{C}$ ), relative humidity (\%), and rainfall (in millimeters) in the months when each visit was done (Supplementary Table S2). Stations were located between 15 and $300 \mathrm{~km}$ from the sampling location and at similar elevation.

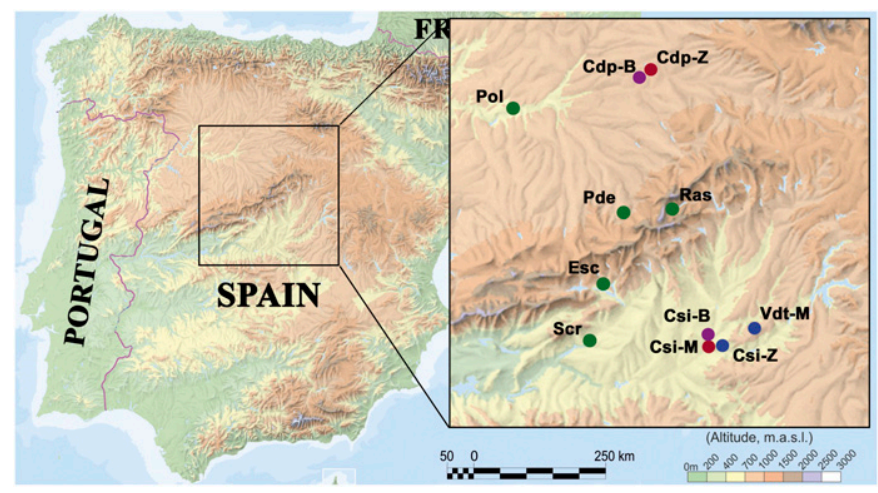

Fig. 1. Geographic distribution of the riparian forests and crop fields visited in this study. The locations of riparian forests (green), melon fields (blue), zucchini fields (red), and bean fields (purple) are shown. Color scale at the bottom right of the image indicates the altitude gradient. Cdp, Ciruelos de Pradales; Csi, Cortijo de San Isidro; Esc, El Escorial; Pde, Palazuelos de Eresma; Pol, Pollos; Ras, Rascafría; Scr, Santa Cruz de Retamar; Vdt, Villamanrique de Tajo.
We also visited cultivated fields of melon (Cucumis melo L.), zucchini (Cucurbita pepo L.), and bean (Vicia faba L.) located near the sampled locations of riparian forests (Fig. 1). At least two fields from each plant species were visited in summer, spring, and autumn, and at each visit 20 to 50 individuals were sampled. For this aim, three leaves of different branches from one out of every three plants were collected along a fixed itinerary of $50 \mathrm{~m}$. Plants were collected regardless of they were showing symptoms.

Sampling effort. The effectiveness of our sampling scheme to represent the total species richness in the monitored locations (sampling effort) was analyzed via accumulation curves. To do so, the number of individuals of each plant species identified at each location and season was used to calculate the mean number of observed plant species. For each location and visit, these accumulation curves were plotted against those built with the Chao 1 estimator, which uses information on the taxa represented only by one or two individuals in a sample to estimate the number of undetected taxa (Gotelli and Chao 2013). Chao 1 richness estimator was computed along with log-linear $95 \%$ confidence intervals in EstimateS version 9.1 (Colwell 2013). We considered evidence of statistical differences between observed and estimated plant species richness when the observed mean lay outside the confidence intervals of the estimated mean (Schenker and Gentleman 2001). In most locations and visits, there were no significant differences between observed and estimated values (Supplementary Fig. S1), indicating that our sampling effort captured most of the plant species richness.

Potyvirus detection and identification. Infection by Potyvirus species was detected in total RNA preparations from leaves via the cetyltrimethylammonium-polyvinyl pyrrolidone method (Chang et al. 1993), which allowed efficient RNA extraction from $83 \%(7,470 / 9,000)$ of the samples. The presence of Potyvirus species was analyzed by real-time reverse transcription RT-PCR. For each run, $10 \mathrm{ng}$ of total plant RNA was added to the Brilliant III SYBR Green Ultra-Fast QRT-PCR Master Mix according to the manufacturer's recommendations. Universal primers NIb2F and NIb3R (Zheng et al. 2010) for species of the genus Potyvirus were used to amplify a region of 271 nucleotides (nt) of the gene that encodes the NIb (Rodríguez-Nevado et al. 2017). RNA purified from Turnip mosaic virus (TuMV), a wellcharacterized potyvirus species, was included as positive control. Amplification was confirmed by electrophoresis in 1.2\% agarose gel stained with ethidium bromide in Tris-acetate-EDTA buffer. PCR products of the expected length were purified using a DNA gel extraction kit and sequenced. Sequences were assembled in MEGA 7 (Kumar et al. 2016). Nucleotide identity of the obtained sequences with the potyviral sequences available in GenBank was analyzed in BLAST. In accordance with the International Committee on Taxonomy of Viruses (King et al. 2012), sequences with a nucleotide identity $>55 \%$ with any known species of the genus Potyvirus were considered as belonging to this genus, and sequences with nucleotide identity between 55 and $76 \%$ were considered as belonging to a non-previously described potyvirus species (Adams et al. 2005). Virus species identification was confirmed by sequencing the CP gene of a subset of isolates assigned to each species. For that, universal potyvirus primer NIbFor1 (Ha et al. 2008) and an Oligo(dT)18 were used to amplify the $3^{\prime}$-end (900 nt) of the Potyvirus isolates, and these fragments were sequenced as described earlier. The $\mathrm{CP}$ gene sequence was obtained for at least one third of the isolates per virus.

Total potyvirus prevalence was calculated as the percentage of infected individuals relative to the total number of analyzed plants. Prevalence for each virus species was calculated as the percentage of infected plants relative to the total number of plants collected from host species.

Phylogenetic analyses. Phylogenetic relationships between the identified potyviruses and the other members of the genus Potyvirus were analyzed via the nucleotide sequences of the 271-nt fragment of the NIb gene. Because species demarcation criteria and 
most Potyvirus phylogenies are based on the $\mathrm{CP}$ gene sequence, we first analyzed whether the sequenced NIb region contained sufficient phylogenetic information to identify different potyvirus species with the same accuracy as the $\mathrm{CP}$. To do so, sequences of potyvirus isolates for which the 271-nt NIb fragment and the fulllength CP genes were available $(n=271)$ were retrieved from GenBank (Supplementary Table S3). These NIb and CP sequences were aligned in MAFFT (Katoh et al. 2002). The alignments were refined with MUSCLE (Edgar 2004), and phylogenetic trees were constructed for each genomic region via Bayesian Markov chain Monte Carlo (MCMC) methods as implemented in MrBayes version 3.2.6 (Ronquist et al. 2012). Alignments were run in the Tamura-Nei substitution model with a gamma distribution of nucleotide substitution rates, because this was selected as the bestfitted nucleotide substitution model in jModelTest version 2.1.10 (Darriba et al. 2012). All analyses were run until relevant parameters converged, with $10 \%$ of the MCMC chains discarded as burn-in. Maximum clade credibility trees, with Bayesian posterior probability values providing a measure of the robustness of each node, were also summarized from the MrBayes tree samples. Congruence between the phylogenies obtained with the NIb and the CP sequences was tested with CopyCat version 2.03 (Meier-Kolthoff et al. 2007). A total of 5 (2\%) nonsignificant and $266(98 \%)$ significant associations between phylogenies of the 271-nt NIb fragment and the $\mathrm{CP}$ sequences of potyvirus isolates were retrieved in the cophylogenetic analysis with a significance threshold of $P=0.050$ (Supplementary Table S4). Thus, results indicated that the tree topology obtained with the 271-nt region of the NIb gene was congruent with that obtained with the CP sequence. Hence, both genomic regions allowed identifying Potyvirus species with comparable accuracy. The same approach was used to build the trees used to analyze the phylogenetic relationships between the sequences obtained in this work and those of known potyviruses.

Genetic diversity and selection pressures in the IbHMV population. The genetic diversity of the IbHMV population was estimated based on the sequence of the 271-nt fragment of the NIb gene of 119 of 144 IbHMV isolates (accession numbers MN531854 to MN531972). We did not use the whole set of 144 sequences because for some hosts or locations only three sequences were available. Thus, to maintain our dataset balanced, we used a maximum of 10 randomly chosen sequences for hosts and locations with larger number of virus sequences available. In these cases, values of the estimated parameters did not differ between the selected subset and the whole sequence dataset (not shown). Virus genetic diversity $(\pi)$ as average pairwise nucleotide difference between sequences, and the mean number of nonsynonymous $\left(d_{N}\right)$ and synonymous $\left(d_{S}\right)$ nucleotide substitutions per site, were estimated via the Kimura-2-parameter nucleotide substitution models implemented in MEGA 7, as determined by jModelTest version 2.1.10. Selection pressures were estimated as the $d_{N} / d_{S}$ ratio. Standard errors of each measure were based on 1,000 bootstrap replicates. Also, the number of IbHMV haplotypes $(\mathrm{H})$ and the haplotype diversity $\left[H_{d}=\left(1-\Sigma x_{i}^{2}\right) n /(n-1)\right.$, where $x_{i}$ is the frequency of an haplotype and $n$ is the sample size (Nei and Tajima 1981)], were calculated in DnaSP version 5 (Librado and Rozas 2009).

Analysis of the genetic structure of the IbHMV populations. IbHMV NIb-based Bayesian trees were constructed as described earlier. The association between IbHMV population geographic origin and host species and the position of each virus isolate in the NIb-based phylogeny were assessed using the association index (AI), parsimony score (PS), and monophyletic clade size (MC) statistics. PS and AI measure the degree to which sequences from virus isolates that share the same geographic origin or host species cluster together across the entire tree topology. MC assesses the same association but for each specific geographic origin or host species. Statistical significance of these indexes was obtained by calculating empirical distributions of the three association statistics from the credible sample (posterior distribution) of NIb-based phylogenetic trees constructed via MCMC methods. Empirical distribution for each index, constructed with $\geq 2,000$ trees, was compared with that resulting from randomizing 1,000 times the position of each sequence in the Bayesian tree. The null hypothesis of random phylogeny-trait associations was rejected at a significance level of $P=0.001$. This analysis was performed in BaTS software (Parker et al. 2008).

Statistical analyses. Differences in IbHMV prevalence between seasons, sampling years, and geographic locations were compared via $\chi^{2}$ tests, with a Yates correction applied when necessary. These statistical analyses were done in SPSS 21.0. (SPSS, Inc., Chicago, IL). IbHMV prevalence and population genetic diversity parameters were normally distributed ( $\mathrm{W} \leq 0.92$; $P \geq 0.391$ ). Thus, mixed effect multiple regression tests were used to analyze the association between ecological factors and IbHMV prevalence and population genetic diversity parameters (Burnham and Anderson 2004). We considered the following factors as predictors of IbHMV prevalence: host plant density and relative abundance, species richness, plant biovolume, temperature, relative humidity and precipitation in the sampled locations (minimal, maximal, and average values), and season. The same ecological factors, with the addition of IbHMV prevalence, were used as predictors of virus population diversity parameters. A set of models that included a global model containing all ecological factors as fixed predictors, and nested models that contained all possible combinations of these predictors, were fitted for each response variable in general linear mixed models (R-library: ASreml-R3 and lmer4). To account for temporal and geographic sources of variance, models contained a random term in which season was nested to sampling cycle and these two factors were nested to location (Snijders and Bosker 2012). Models were constructed with a simultaneous autoregressive variance-covariance matrix to account for time dependency and covariation between predictor variables (i.e., reflecting that measures closer in time are more related than more distant ones). Global and nested models were ranked according to the Akaike information criterion (AIC), and the model with the lowest AIC score was selected as the best ranked. The relative importance of the predictors included in each model was calculated by variance components (R-library: ASreml-R3). Bivariate analyses were done with univariate models that included only the relevant predictor, and with the same model structure than the multivariate ones. Statistical analyses were conducted in R version 3.5.0 (R Core Team 2018).

\section{RESULTS}

Identification and prevalence of potyviruses in riparian forests. Potyvirus prevalence ranged from 2.43 to $7.56 \%$, depending on the season and the sampling year. On average, the highest potyvirus prevalence was observed in summer $\left(5.35 \%, \chi^{2} \geq\right.$ $\left.18.53 ; P<1 \times 10^{-4}\right)$ and the lowest in autumn $\left(2.53 \%, \chi^{2} \geq 13.14\right.$; $\left.P \leq 2.89 \times 10^{-4}\right)$, with intermediate values in spring $(3.70 \%)$. Fluctuations in potyvirus prevalence between sampling cycles (i.e., the group of samplings done in summer and autumn of a given year and in spring of the next one) were observed only in summer: 7.56 to $3.13 \%\left(\chi^{2}=16.36 ; P<1 \times 10^{-4}\right)$.

Potyvirus species present in the 222 infected plants collected from riparian forests were identified. For each isolate, a 271-nt fragment of the NIb gene was sequenced, and we analyzed the sequence identity between these fragments and the same region of the genome from potyvirus sequences available in GenBank, and their phylogenetic relationships (Fig. 2). These analyses indicated the presence of four potyvirus species: 8 of 222 sequences shared 95\% nucleotide identity, and clustered together, with the NIb sequences of TuMV available in GenBank and were identified as belonging to TuMV. Another 14 of 222 sequences shared 79 to $81 \%$ 
nucleotide identity, and clustered together, with the reference NIb sequence of Endive necrotic mosaic virus (ENMV) and were identified as belonging to ENMV. Another 56 of 222 sequences had 95 to $97 \%$ nucleotide identity, and clustered in the same monophyletic group, with the available sequences of Clover yellow vein virus (ClYVV) and were categorized as belonging to ClYVV. Finally, 144 of 222 sequences had 73 to $76 \%$ nucleotide identity with Papaya ringspot virus (PRSV) and clustered in a monophyletic group closely related to the existing PRSV NIb sequences (Fig. 2). Following the International Committee on Taxonomy of Viruses criteria, these sequences were considered as belonging to a non-previously described species of the genus Potyvirus (Adams et al. 2005). Sequencing of the CP gene of 3 to 15 isolates per virus confirmed the species assignment (Supplementary Fig. S2). In particular, the 15 sequences belonging to the putatively new potyvirus species had a nucleotide identity of 71 to $73 \%$ with the reference sequence of PRSV, confirming that these sequences belonged to a nondescribed virus species provisionally named as Iberian hop mosaic virus. The name was chosen because this virus species was consistently detected with the highest prevalence in wild hop (Humulus lupulus) plants (Tables 1 and 2) of Spanish riparian forests within the Iberian Peninsula and in this host generally induced mosaic symptoms (Supplementary Fig. S3). Coinfection with more than one potyvirus was not detected.

ENMV and TuMV were found in a single herbaceous understory host species each (the perennial Andryala ragusina [fam. Compositae] and the annual Sisymbrium irio [fam. Cruciferae], respectively) and at a single riparian forest location (Santa Cruz de Retamar and El Escorial), with prevalence of $11.11 \%$ for ENMV and $20 \%$ for TuMV (Table 1). On the other hand, ClYVV and

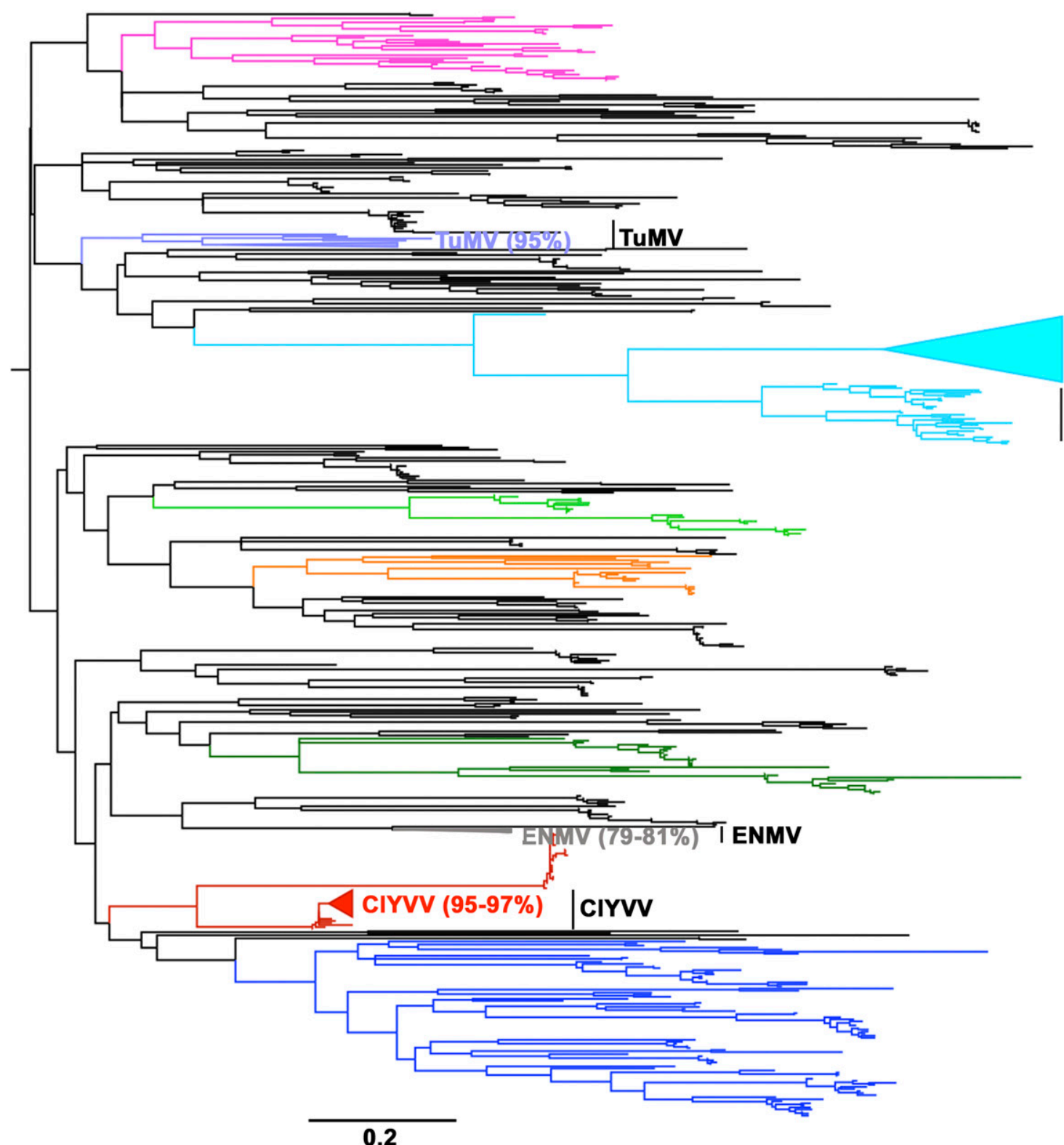

IbHMV (73-76\%)

PRSV

Fig. 2. Potyvirus Bayesian phylogenetic tree based on the nucleotide sequence of a 271 -nt fragment of the NIb gene. Nodes with posterior probability of $\leq 0.80$ were collapsed. The tree is midpoint rooted. Phylogenetic subgroups of potyviruses defined by Shukla et al. 1994 are used as reference and indicated in colored branches. Clusters of sequences obtained in this study are highlighted in colored triangles: ClYVV (red), Clover yellow vein virus; ENMV (gray), Endive necrotic mosaic virus; TuMV (purple); IbHMV (light blue), Iberian hop mosaic virus. Percentage of nucleotide identity of these sequences with those of the closest potyvirus are indicated in parentheses, and the monophyletic groups formed by the sequences of this closest potyvirus are denoted by vertical black bars. BCMV, Bean common mosaic virus; ChiVMV, Chilli veinal mottle virus; PRSV, Papaya ringspot virus; PVY, Potato virus Y; SCMV, Sugarcane mosaic virus; SPFMV, Sweet potato feathery mottle virus; TuMV, Turnip mosaic virus. 
IbHMV were detected infecting plant species from different botanical families, and with broader geographic distribution than ENMV and TuMV (Table 1). The prevalence of CIYVV ranged from 4.60 to $14.55 \%$, whereas prevalence of IbHMV ranged from 2.36 to $50.00 \%$, depending on the host (Table 1). Thus, the identified virus species could be classified into two groups according to their host range: TuMV and EMNV behaved as specialists, whereas IbHMV and CIYVV could be considered generalists. We focused on IbHMV because this potyvirus had the highest prevalence among the identified viruses more consistently found during our surveys, infected the highest number of hosts, and infected plant species of botanical families to which belong crops species cultivated in the area (e.g., Cucurbitaceae, Leguminosae). Indeed, surveys in melon and zucchini (Cucurbitaceae) and in bean (Leguminosae) plants, which are widely cultivated in the area, failed to detect the potyviruses identified in riparian forests, except for IbHMV that was detected in zucchini plants ( 2 of 188, 1.06\%).

Ecological determinants of IbHMV infection risk in riparian forests. IbHMV infected six different host species from taxonomically distant plant families in five riparian forest locations,

TABLE 1. Geographic distribution, host range, and prevalence of Potyvirus species identified in riparian forest of Spain

\begin{tabular}{|c|c|c|c|}
\hline Potyvirus $^{\mathrm{a}}$ & Location $^{b}$ & Host species & $\begin{array}{c}\text { Prevalence } \\
(\%)\end{array}$ \\
\hline \multicolumn{4}{|l|}{ IbHMV } \\
\hline & Esc & Trifolium pratense (Leguminosae) & $22 / 212(10.38)$ \\
\hline & Pde & Trifolium campestre (Leguminosae) & $20 / 110(18.18)$ \\
\hline & & Trifolium pratense (Leguminosae) & $23 / 126(18.25)$ \\
\hline & Pol & Ecballium elaterium (Cucurbitaceae) & $6 / 12(50.00)$ \\
\hline & & Humulus lupulus (Cannabaceae) & $42 / 180(23.33)$ \\
\hline & Ras & Geranium robertianum (Geraniaceae) & $3 / 127(2.36)$ \\
\hline & Scr & Humulus lupulus (Cannabaceae) & $25 / 130(19.23)$ \\
\hline & & Salix atrocinerea (Salicaceae) & $3 / 42(7.14)$ \\
\hline \multicolumn{4}{|l|}{ TuMV } \\
\hline & Esc & Sisymbrium irio (Cruciferae) & $8 / 40(20.00)$ \\
\hline EIVIVIV & Scr & Andryala ragusina (Compositae) & $14 / 126(11.11)$ \\
\hline \multicolumn{4}{|l|}{ ClYVV } \\
\hline & Esc & Trifolium campestre (Leguminosae) & $10 / 150(6.67)$ \\
\hline & & Trifolium pratense (Leguminosae) & $14 / 212(6.60)$ \\
\hline & Pde & Rumex pulcher (Polygonaceae) & $4 / 87(4.60)$ \\
\hline & & Trifolium campestre (Leguminosae) & $16 / 110(14.55)$ \\
\hline & & Trifolium pratense (Leguminosae) & $12 / 126(9.52)$ \\
\hline
\end{tabular}

a IbHMV, Iberian hop mosaic virus; TuMV, Turnip mosaic virus; ENMV, Endive necrotic mosaic virus; ClYVV, Clover yellow vein virus. Virus species are ordered from highest to lowest average prevalence.

b Esc, El Escorial; Pde, Palazuelos de Eresma; Pol, Pollos; Ras, Rascafría; Scr, Santa Cruz de Retamar. and we used IbHMV prevalence as a measure of virus infection risk (Table 2). Virus prevalence is a good proxy of infection risk, provided that virus infection does not induce host mortality. IbHMV prevalence, calculated over 939 host plant samples (12 to 212 samples, depending on the host species), varied across seasons, sampling cycles, and hosts: between $8.33 \%$ in Trifolium pratense (an herbaceous understory perennial of the family Leguminosae) in summer 2015 at El Escorial to 100\% in Ecballium elaterium (an herbaceous understory perennial of the family Cucurbitaceae) in spring 2014 and summer 2015 at Pollos. Overall, higher prevalence was recorded in summer and spring than in autumn $\left(\chi^{2} \geq 9.70, P \leq\right.$ 0.002). In addition, $H$. lupulus (a climbing understory perennial of the family Canabaceae) was the host in which IbHMV was more consistently found, and at a higher prevalence $\left(\chi^{2} \geq 7.22, P \leq 0.007\right)$ (Table 2). Average IbHMV prevalence varied significantly between the first and the second sampling cycles $\left(\chi^{2}=5.40, P=0.020\right)$, but there were no significant differences between these sampling cycles and the third one $\left(\chi^{2} \leq 3.23, P \geq 0.072\right)$ (Table 2$)$.

To further understand the ecological determinants of IbHMV prevalence in riparian forest, multiple regression model selection analyses were used. The following ecological factors were considered as predictors: host plant density and relative abundance, species richness, plant biovolume, temperature and relative humidity (minimal, maximal, and average values), and rainfall in the sampled locations. Note that IbHMV was detected in more than one location, visit, and host. Thus, for multiple regression analyses host- and location-specific values for each visit were used (Table 2). The best-ranked model contained plant relative abundance, plant species richness, mean temperature, and plant biovolume as predictors $(r=0.79, P=0.002)$, with plant relative abundance (63\%) and species richness $(21 \%)$ having the higher relative importance (Table 3 ). Models closely competing with the bestranked one $\left(\Delta_{i}<2\right)$, had similar predictive power $(r=0.81, P \leq$ 0.006 ), and included host plant density and minimum relative humidity as additional predictors but with low relative importance (Table 3). Bivariate analyses revealed a negative association between the relative abundance of host plants and IbHMV prevalence $(r=-0.47 ; P=0.001)$, whereas plant species richness was positively associated with IbHMV prevalence $(r=0.46 ; P=$ 0.003) (Fig. 3A and B).

Ecological determinants of IbHMV population genetic diversity in riparian forests. Analysis of IbHMV population genetic diversity was performed with the virus partial NIb gene sequences. Because IbHMV populations were genetically structured according to geographic location and host of origin (see below), genetic diversity and selection pressure parameters in the virus population were quantified for each location and host

TABLE 2. Prevalence of Iberian hop mosaic virus (IbHMV) in riparian forests of Spain during the monitored period ${ }^{\mathrm{a}}$

\begin{tabular}{|c|c|c|c|c|c|c|c|c|c|c|c|c|c|c|c|c|}
\hline \multirow[b]{3}{*}{ Season } & \multirow{2}{*}{\multicolumn{2}{|c|}{$\begin{array}{l}\text { Esc } \\
\begin{array}{l}\text { Trifolium } \\
\text { pratense }\end{array}\end{array}$}} & \multicolumn{4}{|c|}{ Pde } & \multicolumn{4}{|c|}{ Pol } & \multirow{2}{*}{\multicolumn{2}{|c|}{ 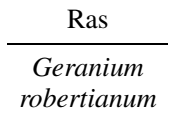 }} & \multicolumn{4}{|c|}{ Scr } \\
\hline & & & \multicolumn{2}{|c|}{$\begin{array}{l}\text { Trifolium } \\
\text { campestre }\end{array}$} & \multicolumn{2}{|c|}{ T. pratense } & \multicolumn{2}{|c|}{$\begin{array}{l}\text { Ecballium } \\
\text { elaterium }\end{array}$} & \multicolumn{2}{|c|}{$\begin{array}{l}\text { Humulus } \\
\text { lupulus }\end{array}$} & & & \multicolumn{2}{|c|}{ H. lupulus } & \multicolumn{2}{|c|}{$\begin{array}{c}\text { Salix } \\
\text { atrocinerea }\end{array}$} \\
\hline & $\mathrm{N}$ & IbHMV $^{a}$ & $\mathrm{~N}$ & $\mathrm{IbHMV}^{\mathrm{a}}$ & $\mathrm{N}$ & $\mathrm{IbHMV}^{\mathrm{a}}$ & $\mathrm{N}$ & $\mathrm{IbHMV}^{\mathrm{a}}$ & $\mathrm{N}$ & $\mathrm{IbHMV}^{\mathrm{a}}$ & $\mathrm{N}$ & $\mathrm{IbHMV}^{\mathrm{a}}$ & $\mathrm{N}$ & IbHMVa $^{a}$ & $\mathrm{~N}$ & IbHMV $^{\mathrm{a}}$ \\
\hline \multicolumn{17}{|l|}{ Sampling cycle 1} \\
\hline Summer 2013 & 10 & 0.00 & 8 & 0.00 & 10 & 0.00 & 0 & - & 24 & 66.67 & 26 & 11.54 & 28 & 0.00 & 6 & 50.00 \\
\hline Autumn 2013 & 17 & 0.00 & 7 & 0.00 & 8 & 0.00 & 0 & - & 0 & - & 0 & - & 0 & - & 8 & 0.00 \\
\hline Spring 2014 & 13 & 0.00 & 18 & 44.44 & 21 & 57.14 & 3 & 100.00 & 23 & 0.00 & 17 & 0.00 & 18 & 50.00 & 7 & 0.00 \\
\hline \multicolumn{17}{|l|}{ Sampling cycle 2} \\
\hline Summer 2014 & 12 & 0.00 & 0 & - & 20 & 45.00 & 6 & 0.00 & 32 & 25.00 & 15 & 0.00 & 30 & 0.00 & 6 & 0.00 \\
\hline Autumn 2014 & 36 & 11.11 & 20 & 0.00 & 14 & 0.00 & 0 & - & 14 & 0.00 & 0 & - & 0 & - & 8 & 0.00 \\
\hline Spring 2015 & 44 & 22.73 & 56 & 21.43 & 37 & 5.41 & 0 & - & 22 & 63.64 & 31 & 0.00 & 20 & 50.00 & 4 & 0.00 \\
\hline \multicolumn{17}{|l|}{ Sampling cycle 3} \\
\hline Summer 2015 & 24 & 8.33 & 1 & 0.00 & 4 & 0.00 & 3 & 100.00 & 16 & 0.00 & 10 & 0.00 & 0 & - & 0 & - \\
\hline Autumn 2015 & 18 & 0.00 & 0 & - & 4 & 0.00 & 0 & - & 11 & 0.00 & 10 & 0.00 & 14 & 7.14 & 3 & 0.00 \\
\hline Spring 2016 & 38 & 15.79 & 0 & - & 8 & 0.00 & 0 & - & 38 & 10.53 & 18 & 0.00 & 20 & 25.00 & 0 & - \\
\hline
\end{tabular}

${ }^{a}$ Esc, El Escorial; N, total number of analyzed plants; Pde, Palazuelos de Eresma; Pol, Pollos; Ras, Rascafría; Scr, Santa Cruz de Retamar. Prevalence calculated as percentage of IbHMV-infected plants relative to the total number of plants analyzed of each host species. 
(Table 4). IbHMV population haplotype number, haplotype diversity, genetic diversity, the number of nonsynonymous and synonymous substitutions per site, and selection pressures varied between locations and hosts $\left(H=3\right.$ to $10 ; H_{d}=0.556$ to $1.000 ; \pi=$ 0.004 to $0.027, d_{N}=0.000$ to $0.020 ; d_{S}=0.006$ to $0.090 ; d_{N} / d_{S}=$ 0.000 to 0.625 ) (Table 4).

The ecological factors affecting IbHMV population $H_{d}, \pi, d_{N}, d_{S}$, and $d_{N} / d_{S}$ were analyzed via multiple regression model selection analyses (Table 3 ). The same predictors as for IbHMV prevalence, and adding this variable as an additional predictor, were used. The best-ranked model explaining $H_{d}$ contained IbHMV prevalence and host density as the most important predictors $(r=0.78 ; P=0.007)$. In this model, virus prevalence had much higher relative importance than host density (57 and 19\%, respectively) (Table 3). Bivariate analysis showed a negative relationship between IbHMV prevalence and $H_{d}(r=-0.62 ; P=0.006)$, whereas the association with host density was nonsignificant $(r=0.32 ; P=0.194$ ) (Fig. 3C and D). The best-ranked model predicting IbHMV genetic diversity $(\pi)$ contained virus prevalence and host relative abundance as the most important predictors $(r=0.71 ; P=0.003)$, the former having higher relative importance than the latter (53 and $24 \%$, respectively). Bivariate analysis showed a negative association between IbHMV prevalence and $\pi(r=-0.66 ; P=0.005)$, whereas the association with host relative abundance was positive $(r=0.62 ; P=0.006)$ (Fig. $3 \mathrm{E}$ and $\mathrm{F}$ ). The best-ranked models predicting IbHMV population $d_{N}$ and $d_{N} / d_{S}$ contained IbHMV prevalence and minimum temperature as the most important predictors, with prevalence having the highest relative importance (46 to 55\%) $(r \geq 0.78 ; P=$ 0.002 ) (Table 3). Bivariate analyses indicated a negative association between virus prevalence and the two parameters $(r \geq 0.46 ; P \leq$ 0.050 ), whereas the association with temperature was at best only marginally significant ( $r \leq 0.45 ; P \geq 0.060)$ (Fig. 3G and H). The best-ranked model predicting $d_{S}$ contained host relative abundance and IbHMV prevalence as the most important predictors $(r=0.81$; $P=0.012$ ), with the former predictor having the highest relative importance $(51 \%)$ (Table 3). Bivariate analyses showed a positive association with host relative importance $(r=0.71 ; P=0.010)$ and a nonsignificant association with virus prevalence $(r=-0.32 ; P=$ 0.189) (Fig. 3I and J).

Analysis of IbHMV speciation mode. To determine the respective roles of allopatric and sympatric speciation in the evolution of IbHMV, we assessed the strength of clustering by host species and location of sample origin within the virus phylogeny. If allopatric speciation were the dominant process, no significant association between phylogeny and host species, and perhaps between phylogeny and location, would be expected. In contrast, if sympatric speciation were the most important evolutionary process, we would expect a significant association between virus phylogeny and both the host species and the location of sampling (Kitchen et al. 2011; Pagán and Holmes 2010).

Both AI and PS statistics revealed a significant association between the IbHMV phylogeny and the location where the sequences were collected $\left(P<1 \times 10^{-5}\right)$. MC statistic indicated that this result was because of the stronger clustering of the sequences collected in El Escorial, Palazuelos de Eresma, Pollos, and Santa Cruz de Retamar $(P \leq 0.001)$ (Fig. 4A). In addition, AI and PS statistics showed a significant genetic structure of the IbHMV populations according to host species $\left(P<1 \times 10^{-5}\right)$. In this case, MC statistics indicated a significant clustering of the virus sequences collected from $H$. lupulus, Trifolium campestre, and T. pratense $(P \leq 0.001)$ (Fig. 4B). Sequences from $S$. atrocinerea (fam. Salicaceae, the only host tree) also clustered together, but the association was not significant, probably because of the small sample size. Together, these data indicate that the IbHMV

TABLE 3. Model selection analyses for Iberian hop mosaic virus (IbHMV) prevalence, population haplotype diversity $\left(H_{d}\right)$, genetic diversity $(\pi)$, number of synonymous $\left(d_{S}\right)$ and nonsynonymous $\left(d_{N}\right)$ substitutions per site, and selection pressures $\left(d_{N} / d_{S}\right)^{\mathrm{a}}$

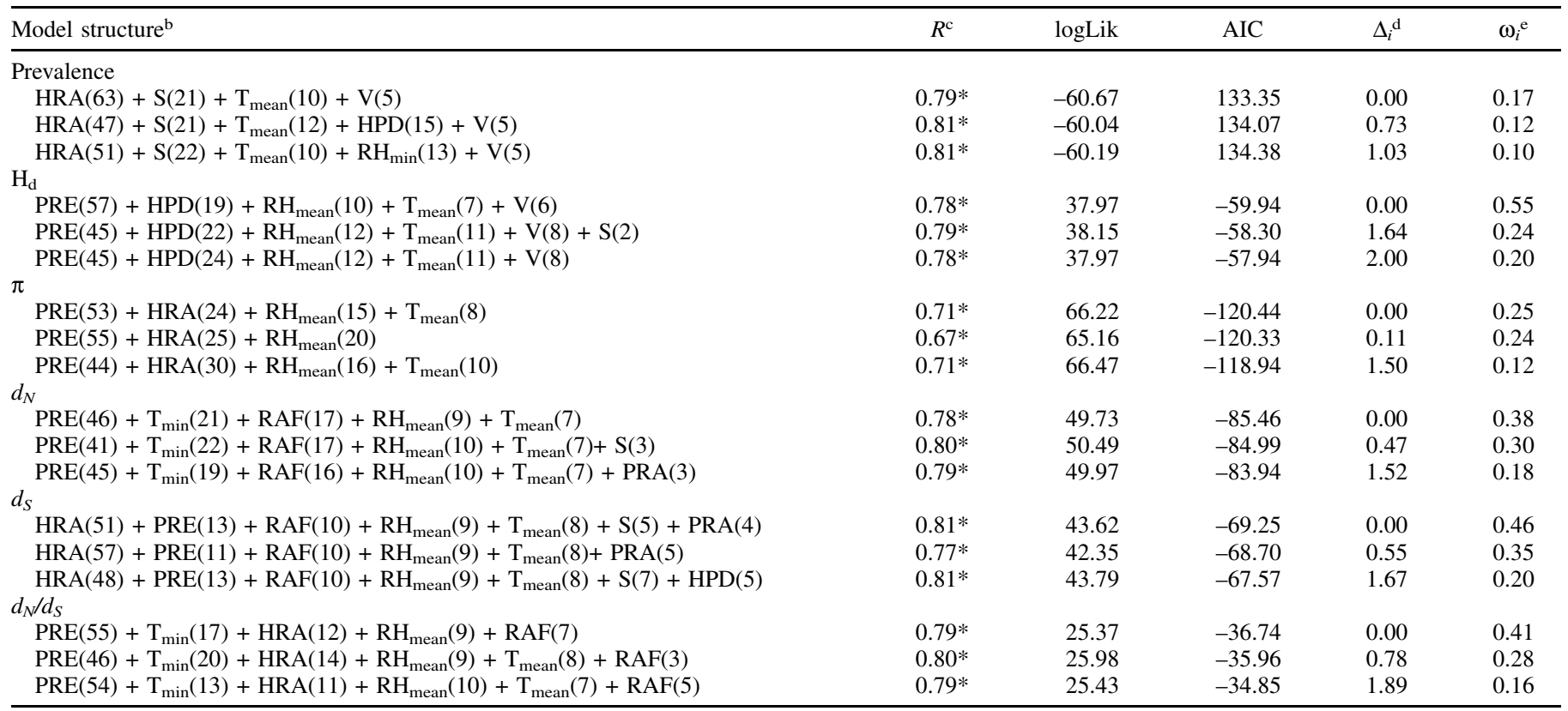

${ }^{a}$ Model structures included host plant density, host relative abundance, plant species richness, plant biovolume, temperature, relative humidity, and rainfall in the sampled locations (minimal, maximal, and average values) as predictors and season as covariate. Potyvirus prevalence was also included as predictor of virus evolution parameters. Best-ranked models are shown. HPD, host plant density; HRA, plant relative abundance; $\mathrm{PRE}$, prevalence; $\mathrm{RAF}$, rainfall; $\mathrm{RH}_{\text {mean }}$, average relative humidity; $\mathrm{S}$, species richness; $\mathrm{T}_{\text {mean }}$, average temperature; $\mathrm{T}_{\min }$, minimum temperature; $\mathrm{V}$, plant biovolume.

b The relative importance $(\%)$ of each predictor variable is shown in parentheses.

c Correlation coefficient. Asterisks indicate significant correlations $(P<0.05)$.

d $\Delta_{i}$ is the difference between the AIC of a given model and that of the best-ranked model, and it quantifies how models compete (best-ranked model, $\Delta_{i}=0$; substantial empirical support, $\Delta_{i}=1-2$; less support, $\Delta_{i}=2-7$; and no support, $\Delta_{i}>10$ ) (Burnham and Anderson 2004).

e AIC model weight as $\omega_{i}=\exp \left(-0.5 \Delta_{i}\right) / \Sigma \exp \left(-0.5 \Delta_{i}\right)$. The larger the $\omega$, the greater the likelihood of the model relatively to the competing models. Maximum $\omega=1$. 

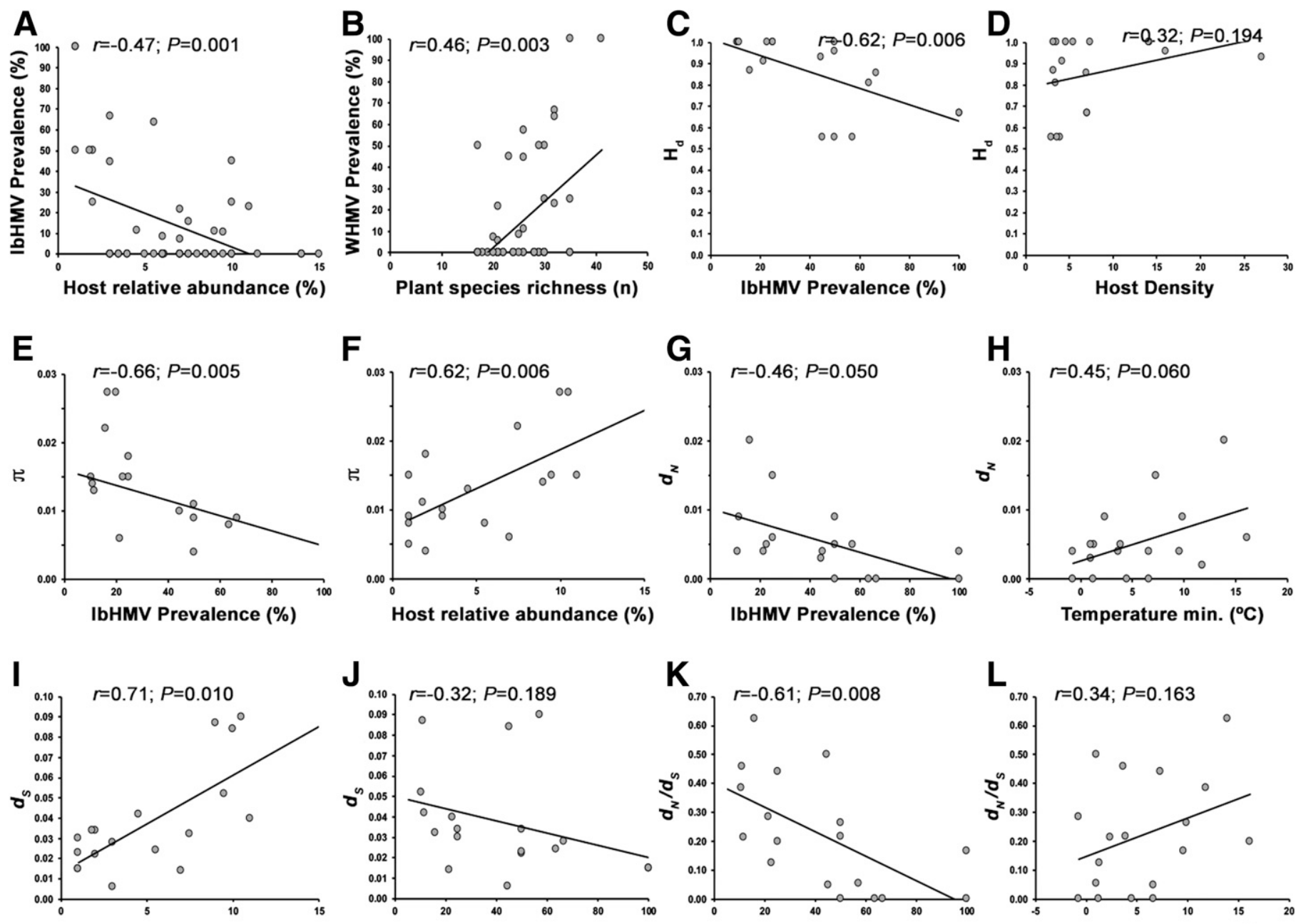

Host relative abundance (\%)

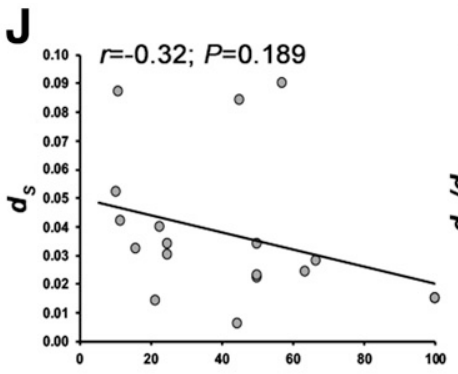

IbHMV Prevalence (\%)

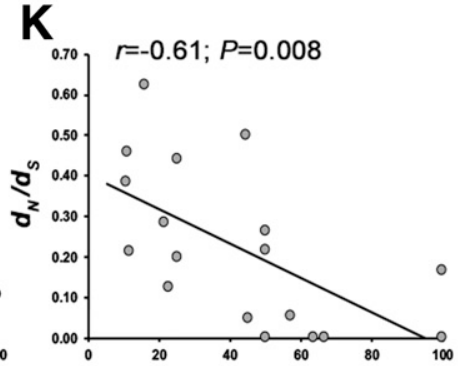

IbHMV Prevalence (\%)

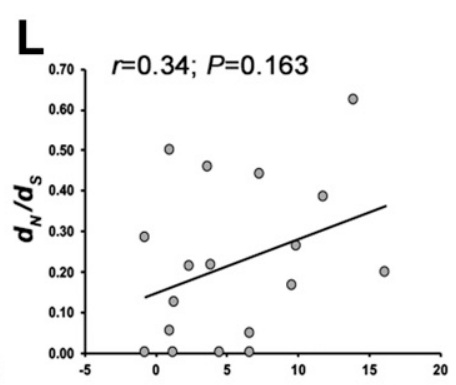

Temperature $\min .\left({ }^{\circ} \mathrm{C}\right)$

Fig. 3. Bivariate relationships between Iberian hop mosaic virus (IbHMV) prevalence and population evolutionary parameters and their best predictors. The associations between $\mathbf{A}$ and $\mathbf{B}$, IbHMV prevalence; $\mathbf{C}$ and $\mathbf{D}$, population haplotype diversity; $\mathbf{E}$ and $\mathbf{F}$, population genetic diversity; $\mathbf{G}$ and $\mathbf{H}$, number of nonsynonymous mutations per site; and $\mathbf{I}$ and $\mathbf{J}$, number of synonymous mutations per site; and $\mathbf{K}$ and $\mathbf{L}$, overall selection pressures.

TABLE 4. Number of haplotypes $(H)$, haplotype diversity $\left(H_{d}\right)$, genetic diversity $(\pi)$, number of nonsynonymous and synonymous substitutions $\left(d_{N}\right.$ and $\left.d_{S}\right)$ per site and selection pressures $\left(d_{N} / d_{S}\right)$ of Iberian hop mosaic virus populations in riparian forests based on the partial NIb gene sequence ${ }^{\mathrm{a}}$

\begin{tabular}{|c|c|c|c|c|c|c|c|c|c|}
\hline Host & Location & Season & $N$ & $H$ & $H_{d} \pm \mathrm{SE}$ & $\pi \pm \mathrm{SE}$ & $d_{N} \pm \mathrm{SE}$ & $d_{S} \pm \mathrm{SE}$ & $d_{N} / d_{S} \pm \mathrm{SE}$ \\
\hline \multirow[t]{2}{*}{ Ecballium elaterium } & Pol & Spring 2014 & 3 & 2 & $0.667 \pm 0.099$ & $0.005 \pm 0.004$ & $0.000 \pm 0.000$ & $0.015 \pm 0.011$ & $0.000 \pm 0.000$ \\
\hline & Pol & Summer 2015 & 3 & 2 & $0.667 \pm 0.099$ & $0.008 \pm 0.004$ & $0.004 \pm 0.004$ & $0.015 \pm 0.011$ & $0.267 \pm 0.056$ \\
\hline Geranium robertianum & Ras & Summer 2013 & 3 & 3 & $1.000 \pm 0.074$ & $0.013 \pm 0.003$ & $0.009 \pm 0.005$ & $0.042 \pm 0.004$ & $0.214 \pm 0.031$ \\
\hline \multirow{5}{*}{ Humulus lupulus } & Pol & Summer 2014 & 8 & 8 & $1.000 \pm 0.004$ & $0.018 \pm 0.006$ & $0.015 \pm 0.006$ & $0.034 \pm 0.024$ & $0.441 \pm 0.038$ \\
\hline & Pol & Spring 2015 & 7 & 4 & $0.810 \pm 0.016$ & $0.008 \pm 0.004$ & $0.000 \pm 0.000$ & $0.024 \pm 0.012$ & $0.000 \pm 0.000$ \\
\hline & Pol & Spring 2016 & 4 & 4 & $1.000 \pm 0.031$ & $0.015 \pm 0.004$ & $0.002 \pm 0.000$ & $0.052 \pm 0.005$ & $0.038 \pm 0.006$ \\
\hline & Scr & Spring 2014 & 9 & 2 & $0.556 \pm 0.008$ & $0.004 \pm 0.003$ & $0.000 \pm 0.000$ & $0.022 \pm 0.018$ & $0.000 \pm 0.000$ \\
\hline & Scr & Spring 2016 & 4 & 4 & $1.000 \pm 0.031$ & $0.015 \pm 0.006$ & $0.006 \pm 0.002$ & $0.030 \pm 0.013$ & $0.200 \pm 0.026$ \\
\hline Salix atrocinerea & Scr & Summer 2013 & 3 & 3 & $1.000 \pm 0.074$ & $0.011 \pm 0.006$ & $0.009 \pm 0.005$ & $0.034 \pm 0.029$ & $0.265 \pm 0.042$ \\
\hline \multirow[t]{2}{*}{ Trifolium campestre } & Pde & Spring 2014 & 8 & 6 & $0.929 \pm 0.007$ & $0.010 \pm 0.004$ & $0.003 \pm 0.002$ & $0.006 \pm 0.006$ & $0.500 \pm 0.025$ \\
\hline & Pde & Spring 2015 & 10 & 7 & $0.911 \pm 0.006$ & $0.006 \pm 0.003$ & $0.004 \pm 0.003$ & $0.014 \pm 0.010$ & $0.286 \pm 0.020$ \\
\hline \multirow[t]{3}{*}{ Trifolium pratense } & Esc & Autumn 2014 & 4 & 4 & $1.000 \pm 0.031$ & $0.014 \pm 0.006$ & $0.004 \pm 0.003$ & $0.087 \pm 0.046$ & $0.046 \pm 0.019$ \\
\hline & Esc & Spring 2015 & 10 & 10 & $1.000 \pm 0.002$ & $0.015 \pm 0.005$ & $0.005 \pm 0.003$ & $0.040 \pm 0.022$ & $0.125 \pm 0.030$ \\
\hline & Esc & Summer 2015 & 2 & - & - & - & - & - & - \\
\hline
\end{tabular}

a Esc, El Escorial; N, number of sequences; Pde, Palazuelos de Eresma; Pol, Pollos; Ras, Rascafría; Scr, Santa Cruz de Retamar; SE, standard error. 
population is genetically structured according to the location of origin and the host. These results suggest that IbHMV speciation tends to occur within the same host species and in the same geographic area, which is compatible with genetic diversification through sympatric speciation, at least for certain hosts.

\section{DISCUSSION}

The high pathogenic potential of plant viruses for crops has driven current understanding on their diversity and epidemiology (Cooper and Jones 2006; Pagán and García-Arenal 2018). In contrast, little is known about the diversity and prevalence of native viruses in wild plant populations (Bernardo et al. 2017; Pagán and García-Arenal 2018; Susi et al. 2019) and even less about the factors that determine these traits (Rodelo-Urrego et al. 2015; RodríguezNevado et al. 2017). Characterizing such determinants is central to understanding the evolution and epidemiology of plant viruses and the potential of viruses native to wild ecosystems to cause epidemics in crops (Alexander et al. 2014). We characterized the diversity and prevalence of potyviruses, one of the largest genera of plant viruses, in riparian forests of Spain. In this ecosystem, we identified the ecological determinants of virus prevalence and genetic diversity, and we explored the potential of these viruses to spread to nearby crops.

To date, the majority of ecological studies of viruses in wild hosts have focused on individual plant species (Rodríguez-Nevado et al. 2017; Susi et al. 2019) or on viruses that typically infect crops (Malmstrom et al. 2005; McLeish et al. 2017; Seabloom et al. 2013). Even when broader approaches are chosen, for instance in metagenomic analyses, samples often represent pools of many hosts, and little or no connection can be made between the virus and its corresponding hosts (Roossinck 2015; Roossinck and GarcíaArenal 2015). We took a comprehensive sampling approach that allowed inventorying the majority of the plant diversity in riparian forests and characterizing both the identity and host range of known and unknown virus species of the genus Potyvirus. Identification of the potyviruses present in riparian forests indicated the presence of virus species that typically infect crops: ClYVV, ENMV, and TuMV. ClYVV is one of the most prevalent potyviruses in legumes, causing important economic losses in crops and pastures worldwide (Andrade et al. 2007). Accordingly, in riparian forests ClYVV was detected in Trifolium species (Leguminosae). More unexpected was the detection of infected Rumex pulcher (another herbaceous understory perennial, fam. Polygonaceae). This plant species has not been previously described as a ClYVV host, which indicates that the virus host range may go beyond Leguminosae species. The other two crop viruses, ENMV and TuMV, are present in the Mediterranean basin in a large set of cultivated plants, mainly of the family Compositae (Desbiez et al. 2017) and Cruciferae (Walsh and Jenner 2002), respectively. Coherently with their known host ranges, in riparian forests these potyviruses were identified
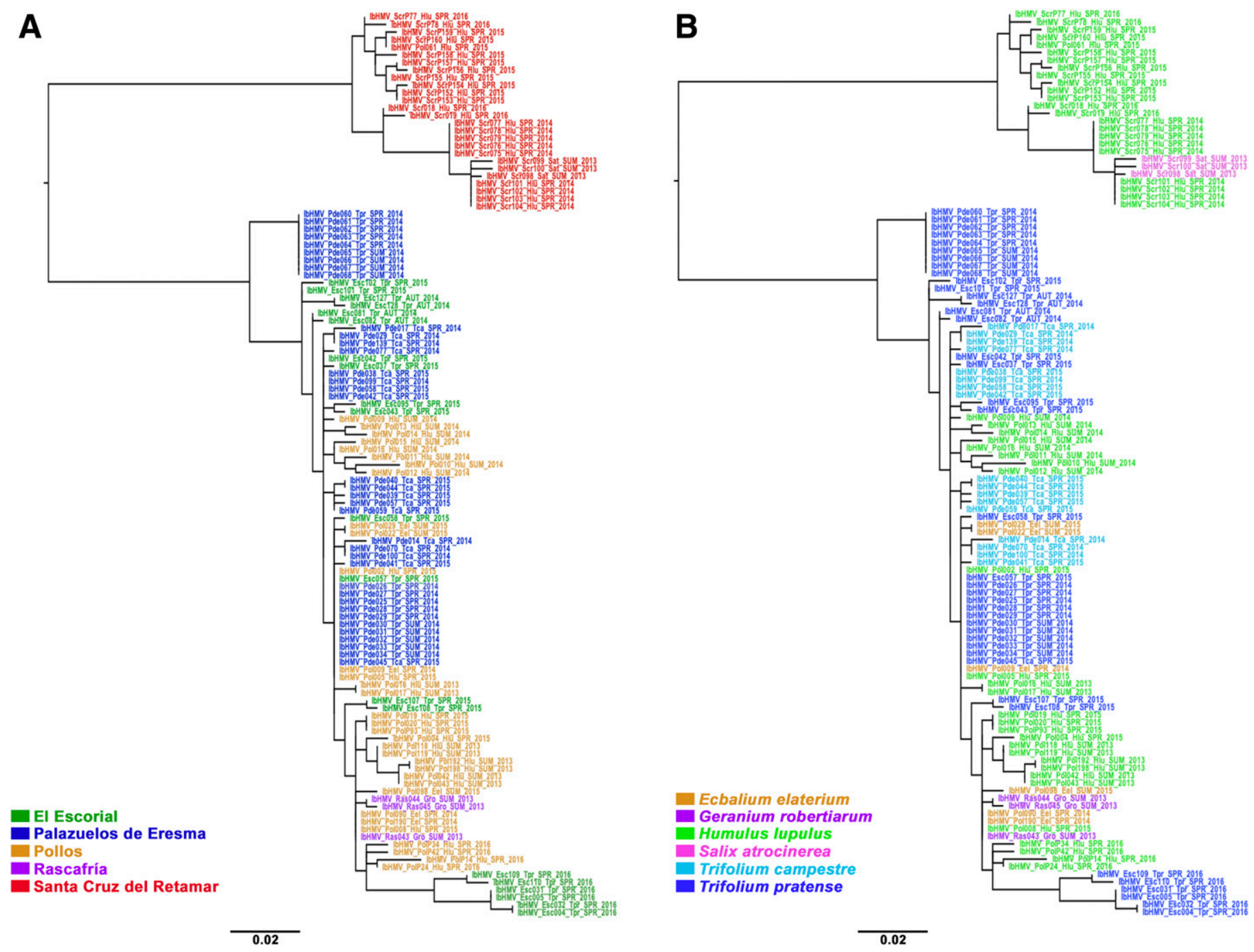

Fig. 4. Bayesian phylogeny based on the 271-nt fragment of the NIb gene representing the association between A, the Iberian hop mosaic virus (IbHMV) phylogeny and the location of origin, and $\mathbf{B}$, the host plant species. Nodes with posterior probability of $\leq 0.80$ were collapsed. The tree is midpoint rooted. 
infecting $A$. ragusina (Compositae) and S. irio (Cruciferae). We also identified a new potyvirus species native from riparian forests: IbHMV. IbHMV had a broader host range and geographic distribution than the other identified potyviruses, infecting plant species from different botanical families (Cannabaceae, Cucurbitaceae, Leguminosae, Geraniaceae, and Salicaceae). The generalist behavior of IbHMV is consistent with that of most viruses described in wild plants (Cooper and Jones 2006), and its host range suggests that this virus was more likely to spread to nearby agroecosystems where cucurbits and legumes are cultivated. Indeed, it was the only virus identified in riparian forests that was also detected in crops. It should be noted that analyses of E. elaterium plants (Cucurbitaceae) collected at the edges of the sampled crop fields indicated the presence of IbHMV at a low prevalence $(11.11 \%, 2$ of 18), which would facilitate the migration of this virus into crops.

The higher prevalence of IbHMV in riparian forests and its presence in nearby crops prompted us to analyze the ecological factors affecting virus infection risk in this wild ecosystem. The best-ranked model predicting virus prevalence (a proxy of infection risk) contained host relative abundance as the main predictor, with a negative association between these traits. However, theory predicts a positive association between host relative abundance and virus infection risk (Keesing et al. 2006; Ostfeld and Keesing 2012). This difference with theoretical predictions would be explained if virus infection increases host mortality, such that higher virus prevalence results in larger decrease of the host population size (and therefore of host relative abundance). Indeed, some examples exist of plant viruses that cause obvious diseases in wild hosts (Malmstrom et al. 2005; Prendeville et al. 2014; Rodríguez-Nevado et al. 2017), affecting plant population size. It would also be explained if plant isolation favors increased prevalence through attracting virus vectors (Way and Heathcote 1966). Finally, it would be explained if the best hosts are the less common plants (McLeish et al. 2017). Here, we did not analyze IbHMV virulence or host competence. On the other hand, the best hosts of IbHMV in terms of prevalence level (H. lupulus, E. elaterium) were rare species in riparian forests, which would explain why IbHMV infection risk is higher in hosts with lower relative abundance. This observation agrees with previous analyses indicating that less common hosts determine the prevalence of generalist viruses such as Cucumber mosaic virus (CMV) in other habitats of Spain (McLeish et al. 2017). Interestingly, the hosts in which IbHMV was more prevalent were perennials. This is consistent with the hypothesis that low-abundance perennial hosts may determine virus prevalence by acting as longterm "refuges" for the virus when other hosts (or vectors) are absent (Hamer et al. 2011; Streicker et al. 2013). The importance of lowabundance hosts for IbHMV prevalence may also explain why species richness and plant biovolume are secondary predictors of IbHMV prevalence. Higher species richness would increase the probability of rare hosts to appear, hence the positive association between virus prevalence and species richness in support of the amplification effect hypothesis. Also, the appearance of these infrequent host species, whose size is generally above the average of plants in the ecosystem, would result in larger plant biovolume.

Our results also indicate that epidemiological and ecological changes may result in genetic modifications in the virus population. Indeed, IbHMV prevalence was a major predictor of the virus population genetic and haplotype diversities. A positive association between virus prevalence and population genetic diversity in wild hosts has been reported for chiltepin-infecting begomoviruses and for Mediterranean ruda virus (MeRV) (Rodelo-Urrego et al. 2015; Rodríguez-Nevado et al. 2017). This positive association was attributed to population size effects: The higher the prevalence, the larger the population size, which in turn increases population genetic diversity (Burdon and Thrall 2008; Ellegren and Galtier 2016). At odds, IbHMV prevalence was negatively associated with population genetic and haplotype diversities, such that virus population size is unlikely to be a primary determinant of IbHMV evolution. As mentioned earlier, the hosts in which IbHMV prevalence is generally lower (i.e., Trifolium species) are the more abundant in riparian forests. Therefore, hosts with higher population sizes harbor virus populations with larger genetic diversity. These larger population sizes are likely to result in higher host population genetic diversity, because the best IbHMV hosts are rare species, and their population genetic diversity is expected to be low (Ellegren and Galtier 2016). Indeed, analyses of European populations of $H$. lupulus showed high genetic homogeneity (Murakami et al. 2006), which was not observed in Trifolium populations (Dias et al. 2008). Thus, our results suggest a positive association between host and virus population genetic diversities, consistent with analyses in animal viruses (Rodríguez-Nevado et al. 2018). Such association between host and virus population genetic diversities has been attributed to host adaptation by the parasite (Agrawal and Lively 2010; Haldane 1949; Hamilton 1980). Two lines of evidence suggest that this may also be the case for IbHMV. First, IbHMV prevalence was also the major predictor of $d_{N}$ and $d_{N} / d_{S}$ (traits linked to selection), these traits showing a negative association, but not of $d_{S}$ (generally associated with neutral evolution). Second, IbHMV sequences largely clustered according to host species, which is also compatible with host adaptation. This rationale would also explain the role of host relative abundance as the other main predictor of IbHMV genetic diversity and the positive association between these two traits. However, changes in population genetic diversity of MeRV and chiltepin-infecting begomoviruses has been attributed to neutral evolution (Rodelo-Urrego et al. 2015; Rodríguez-Nevado et al. 2017). Interestingly, these viruses have host ranges limited to a single plant species or to a few within the same botanical family (specialists), which was not the case of the generalist IbHMV. Hence, our data support the predictions for the effect of host range on parasite evolution (McLeish et al. 2018).

Finally, we present evidence of a statistically significant association between IbHMV phylogeny and both host specificity and geographic origin, which suggests that this potyvirus species may have arisen within the same host species and in a restricted geographic area, as is expected under a process of sympatric speciation. Equivalent phylogenetic studies of speciation processes in other families of RNA viruses most often indicated speciation through sympatric processes for both plant (Pagán and Holmes 2010) and animal (Kitchen et al. 2011) hosts. In riparian forests, the predominance of IbHMV sympatric speciation may be expected, given that both plants and aphid vectors have a limited ability to move large geographic distances and that the anthropogenic factors that would assist allopatric speciation (such as increased transportation of plants) probably have little effect on the analyzed ecosystems that have not undergone human management. However, it is important to note that the lack of information on the host range of IbHMV in other geographic regions or habitats may be biasing this analysis against the detection of allopatric processes.

Some cautionary comments are warranted, however. For instance, the analyses of the association between potyvirus prevalence or genetic diversity and ecological factors are based on data from five locations. Moreover, the number of IbHMV sequences available per location, host, and season ranged between 3 and 10 . This might represent a small sample size. However, it was enough to detect significant correlations between the studied parameters. A similar caveat could be applicable to our sampling effort: Although our accumulation curves indicate that we generally captured most of the plant species richness of each monitored location, they also show that in some cases we could have missed some low-abundance plant species. Still, our sampling scheme was exhaustive enough to detect the importance of low-abundance plants in virus epidemiology. In addition, although the best-ranked multivariate models explained a large proportion of the variation in IbHMV infection risk and population genetic diversity, other factors not considered here could also play a role in IbHMV epidemiology and evolution. As mentioned earlier, host genetic diversity and parasite virulence 
have been also reported as important determinants of virus infection risk and population genetic diversity in wild ecosystems (Pagán et al. 2012; Rodelo-Urrego et al. 2015; Rodríguez-Nevado et al. 2017). Unfortunately, we did not collect measures of virulence in our samplings, and a lack of information on the genomic sequences of some plant hosts identified in this work prevented including host genetic diversity in our analyses. Finally, we did not include information on IbHMV vectors. Identifying and collecting information on the virus vectors in riparian forests was beyond the scope of this work, but surely it will account for part of the variation in virus epidemiology and evolution that our models cannot explain. The identification of relative humidity, rainfall, or temperature-factors known to influence the population dynamics of virus vectors (Díaz and Fereres 2005) - as minor predictors of IbHMV prevalence and genetic diversity support this idea. Analyses in other host-virus systems would help to test the generality of our observations.

In summary, the results of this work provide novel information on the determinants of plant virus epidemiology and evolution in wild ecosystems and highlight the importance of considering the interplay between the ecology, epidemiology, and genetic diversity of plant host and virus populations in order to fully understand plant-virus interactions.

\section{ACKNOWLEDGMENTS}

We thank Marisa López-Herranz and Miriam Gil-Valle for excellent technical assistance.

\section{LITERATURE CITED}

Adams, M. J., Antoniw, J. F., and Fauquet, C. M. 2005. Molecular criteria for genus and species discrimination within the family Potyviridae. Arch. Virol. 150:459-479.

Agrawal, A., and Lively, C. M. 2010. Infection genetics: gene-for-gene versus matching-alleles models and all points in between. Evol. Ecol. Res. 4: 79-90.

Alexander, H. M., Mauck, K. E., Whitfield, A. E., Garrett, K. A., and Malmstrom, C. M. 2014. Plant-virus interactions and the agro-ecological interface. Eur. J. Plant Pathol. 138:529-547.

Anderson, P. K., Cunningham, A. A., Patel, N. G., Morales, F. J., Epstein, P. R., and Daszak, P. 2004. Emerging infectious diseases of plants: pathogen pollution, climate change and agrotechnology drivers. Trends Ecol. Evol. 19:535-544.

Andrade, M., Sato, M., and Uyeda, I. 2007. Two resistance modes to Clover yellow vein virus in pea characterized by a green fluorescent protein-tagged virus. Phytopathology 97:544-550.

Barrett, L. G., Thrall, P. H., Burdon, J. J., and Linde, C. C. 2008. Life history determines genetic structure and evolutionary potential of host-parasite interactions. Trends Ecol. Evol. 23:678-685.

Bernardo, P., Charles-Dominique, T., Barakat, M., Ortet, P., Fernandez, E., Filloux, D., Hartnady, P., Rebelo, T. A., Cousins, S. R., Mesleard, F., Cohez, D., Yavercovski, N., Varsani, A., Harkins, G. W., Peterschmitt, M., Malmstrom, C. M., Martin, D. P., and Roumagnac, P. 2017. Geometagenomics illuminates the impact of agriculture on the distribution and prevalence of plant viruses at the ecosystem scale. ISME J. 12:173-184.

Blanco, E., Casado, M. A., Costa, M., Escribano, R., García, M., Génova, M., Gómez, A., Gómez, F., Moreno, J. C., and Morla, C. 2005. Los Bosques Ibéricos. Una Interpretación Geobotánica, 4th ed. Editorial Planeta, Barcelona.

Borer, E. T., Seabloom, E. W., Mitchell, C. E., and Power, A. G. 2010. Local context drives infection of grasses by vector-borne generalist viruses. Ecol. Lett. 13:810-818.

Brown, J. K. M., and Tellier, A. 2011. Plant-parasite coevolution: bridging the gap between genetics and ecology. Annu. Rev. Phytopathol. 49:345-367.

Burdon, J. J., and Thrall, P. H. 2008. Pathogen evolution across the agroecological interface: implications for disease management. Evol. Appl. 1: 57-65.

Burnham, K. P., and Anderson, D. R. 2004. Multimodel inference: understanding AIC and BIC in model selection. Sociol. Methods Res. 33: 261-304.

Castro, I., Casado, M. Á., Ramírez-Sanz, L., de Miguel, J. M., Costa, M., and Pineda, F. D. 1996. Funciones de estimación de la biomasa aérea de varias especies del matorral mediterráneo del centro de la península Ibérica. Orsis 11:107-116.

Chang, S., Puryear, J., and Cairney, J. 1993. A simple and efficient method for isolating RNA from pine trees. Plant Mol. Biol. Report. 11:113-116.

Colwell, R. K. 2013. EstimateS: statistical estimation of species richness and shared species from samples, version 9.0. http://purl.oclc.org/estimates.

Cooper, I., and Jones, R. A. 2006. Wild plants and viruses: under-investigated ecosystems. Adv. Virus Res. 67:1-47.

Darriba, D., Taboada, G. L., Doallo, R., and Posada, D. 2012. jModelTest 2: more models, new heuristics and parallel computing. Nat. Methods 9:772.

Desbiez, C., Wipf-Scheibel, C., Millot, P., Verdin, E., Dafalla, G., and Lecoq, H. 2017. New species in the papaya ringspot virus cluster: Insights into the evolution of the PRSV lineage. Virus Res. 241:88-94.

Dias, P. M. B., Julier, B., Sampoux, J.-P., Barre, P., and Dall'Agnol, M. 2008. Genetic diversity in red clover (Trifolium pratense L.) revealed by morphological and microsatellite (SSR) markers. Euphytica 160:189-205.

Diaz, B. M., and Fereres, A. 2005. Life table and population parameters of Nasonoviaribisnigri (Homoptera: Aphididae) at different constant temperatures. Environ. Entomol. 34:527-534.

Edgar, R. C. 2004. MUSCLE: multiple sequence alignment with high accuracy and high throughput. Nucleic Acids Res. 32:1792-1797.

Elena, S. F., Bedhomme, S., Carrasco, P., Cuevas, J. M., de la Iglesia, F., Lafforgue, G., Lalić, J., Pròsper, À., Tromas, N., and Zwart, M. P. 2011. The evolutionary genetics of emerging plant RNA viruses. Mol. Plant-Microbe Interact. 24:287-293.

Elena, S. F., Fraile, A., and García-Arenal, F. 2014. Evolution and emergence of plant viruses. Adv. Virus Res. 88:161-191.

Ellegren, H., and Galtier, N. 2016. Determinants of genetic diversity. Nat. Rev. Genet. 17:422-433.

Fraile, A., McLeish, M. J., Pagán, I., González-Jara, P., Piñero, D., and García-Arenal, F. 2017. Environmental heterogeneity and the evolution of plant-virus interactions: Viruses in wild pepper populations. Virus Res. 241:68-76.

Garrett, K. A., Dendy, S. P., Frank, E. E., Rouse, M. N., and Travers, S. E. 2006. Climate change effects on plant disease: genomes to ecosystems. Annu. Rev. Phytopathol. 44:489-509.

Gavilán, R. G., Vilches, B., Gutiérrez-Girón, A., Blanquer, J. M., and Escudero, A. 2018. Sclerophyllous versus deciduous forests in the Iberian Peninsula: A standard case of Mediterranean climatic vegetation distribution. Pages 101-116 in: Geographical Changes in Vegetation and Plant Functional Types. Geobotany Studies: Basics, Methods and Case Studies. Springer Nature, London.

Gotelli, N. J., and Chao, A. 2013. Measuring and estimating species richness, species diversity, and biotic similarity from sampling data. Pages 195-211 in: Encyclopedia of Biodiversity. Academic Press, Cambridge, UK.

Ha, C., Coombs, S., Revill, P. A., Harding, R. M., Vu, M., and Dale, J. L. 2008. Design and application of two novel degenerate primer pairs for the detection and complete genomic characterization of potyviruses. Arch. Virol. $153: 25-36$.

Haldane, J. B. S. 1949. Disease and evolution. Ric. Sci. 19:S68-S76.

Hamer, G. L., Chaves, L. F., Anderson, T. K., Kitron, U. D., Brawn, J. D., Ruiz, M. O., Loss, S. R., Walker, E. D., and Goldberg, T. L. 2011. Finescale variation in vector host use and force of infection drive localized patterns of West Nile virus transmission. PLoS One 6:e23767.

Hamilton, W. D. 1980. Sex versus non-sex versus parasite. Oikos 35:282-290.

Herms, D. A., and Mattson, W. J. 1992. The dilemma of plants: to grow or defend. Q. Rev. Biol. 67:283-335.

Huyse, T., Poulin, R., and Theron, A. 2005. Speciation in parasites: a population genetics approach. Trends Parasitol. 21:469-475.

Johnson, P. T., Ostfeld, R. S., and Keesing, F. 2015. Frontiers in research on biodiversity and disease. Ecol. Lett. 18:1119-1133.

Jones, R. A. C. 2009. Plant virus emergence and evolution: origins, new encounter scenarios, factors driving emergence, effects of changing world conditions, and prospects for control. Virus Res. 141:113-130.

Katoh, K., Misawa, K., Kuma, K., and Miyata, T. 2002. MAFFT: a novel method for rapid multiple sequence alignment based on fast Fourier transform. Nucleic Acids Res. 30:3059-3066.

Keesing, F., Holt, R. D., and Ostfeld, R. S. 2006. Effects of species diversity on disease risk. Ecol. Lett. 9:485-498.

Kennelly, M., O’Mara, J., Rivard, C., Miller, G. L., and Smith, D. 2012. Introduction to abiotic disorders in plants. Plant Health Instr. 10:1094.

King, A. M., Lefkowitz, E., Adams, M. J., and Carstens, E. B. 2012. Virus Taxonomy: Ninth Report of the International Committee on Taxonomy of Viruses. Elsevier, Amsterdam.

Kitchen, A., Shackelton, L. A., and Holmes, E. C. 2011. Family level phylogenies reveal modes of macroevolution in RNA viruses. Proc. Natl. Acad. Sci. USA 108:238-243.

Kumar, S., Stecher, G., and Tamura, K. 2016. MEGA7: Molecular Evolutionary Genetics Analysis version 7.0 for bigger datasets. Mol. Biol. Evol. $33: 1870-1874$ 
Lefeuvre, P., Martin, D. P., Elena, S. F., Shepherd, D. N., Roumagnac, P., and Varsani, A. 2019. Evolution and ecology of plant viruses. Nat. Rev. Microbiol. 17:632-644.

Librado, P., and Rozas, J. 2009. DnaSP v5: a software for comprehensive analysis of DNA polymorphism data. Bioinformatics 25:1451-1452.

Malmstrom, C. M., and Alexander, H. M. 2016. Effects of crop viruses on wild plants. Curr. Opin. Virol. 19:30-36.

Malmstrom, C. M., McCullough, A. J., Johnson, H. A., Newton, L. A., and Borer, E. T. 2005. Invasive annual grasses indirectly increase virus incidence in California native perennial bunchgrasses. Oecologia 145: 153-164.

Malpica, J. M., Sacristán, S., Fraile, A., and García-Arenal, F. 2006. Association and host selectivity in multi-host pathogens. PLoS One 1:e41.

Mayr, E. 1963. Animal Species and Evolution. The Belknap Press, Cambridge, MA.

McGarigal, K., Tagil, S., and Cushman, S. A. 2009. Surface metrics: an alternative to patch metrics for the quantification of landscape structure. Landsc. Ecol. 24:433-450.

McLeish, M., Fraile, A., and García-Arenal, F. 2018. Ecological complexity in plant virus host range evolution. Adv. Virus Res. 101:293-339.

McLeish, M., Sacristán, S., Fraile, A., and García-Arenal, F. 2017. Scale dependencies and generalism in host use shape virus prevalence. Proc. R. Soc. B. 284:20172066.

Meier-Kolthoff, J. P., Auch, A. F., Huson, D. H., and Göker, M. 2007. CopyCat: cophylogenetic analysis tool. Bioinformatics 23:898-900.

Montes, N., Alonso-Blanco, C., and García-Arenal, F. 2019. Cucumber mosaic virus infection as a potential selective pressure on Arabidopsis thaliana population. PLoS Pathog 15:e1007810.

Moreno-Pérez, M. G., Pagán, I., Aragón-Caballero, L., Cáceres, F., Fraile, A., and García-Arenal, F. 2014. Ecological and genetic determinants of Pepino mosaic virus emergence. J. Virol. 88:3359-3368.

Murakami, A., Darby, P., Javornik, B., Pais, M. S. S., Seigner, E., Lutz, A., and Svoboda, A. 2006. Molecular phylogeny of wild hops, Humulus lupulus L. Heredity 97:66-74.

Nei, M., and Tajima, F. 1981. Genetic drift and estimation of effective population size. Genetics 98:625-640.

Ostfeld, R. S., and Keesing, F. 2012. Effects of host diversity on infectious disease. Annu. Rev. Ecol. Evol. Syst. 43:157-182.

Pagán, I. 2018. The diversity, evolution and epidemiology of plant viruses: a phylogenetic view. Infect. Genet. Evol. 65:187-199.

Pagán, I., Fraile, A., Fernández-Fueyo, E., Montes, N., Alonso-Blanco, C., and García-Arenal, F. 2010. Arabidopsis thaliana as a model for the study of plant-virus co-evolution. Philos. Trans. R. Soc. B 365:1983-1995.

Pagán, I., Fraile, A., and García-Arenal, F. 2016. Evolution of the interactions of viruses with their plant hosts. Pages 127-154 in: Virus Evolution: Current Research and Future Directions, S. C. Weaver, M. Denison, M. Roossinck, and M. Vignuzzi, eds. Caister Academic Press, Poole, UK.

Pagán, I., and García-Arenal, F. 2018. Population genomics of plant viruses. Pages 233-265 in: Population Genomics. M. Polz and O. Rajora, eds. Springer, New York, Ny.

Pagán, I., González-Jara, P., Moreno-Letelier, A., Rodelo-Urrego, M., Fraile, A., Piñero, D., and García-Arenal, F. 2012. Effect of biodiversity changes in disease risk: exploring disease emergence in a plant-virus system. PLoS Pathog 8:e1002796.

Pagán, I., and Holmes, E. C. 2010. Long-term evolution of the Luteoviridae: time scale and mode of virus speciation. J. Virol. 84:6177-6187.

Parker, J., Rambaut, A., and Pybus, O. G. 2008. Correlating viral phenotypes with phylogeny: accounting for phylogenetic uncertainty. Infect. Genet. Evol. 8:239-246.

Prendeville, H. R., Tenhumberg, B., and Pilson, D. 2014. Effects of virus on plant fecundity and population dynamics. New Phytol. 202:1346-1356.

R Core Team. 2018. R: A language and environment for statistical computing. R Foundation for Statistical Computing, Vienna, Austria.

Randolph, S. E., and Dobson, A. D. M. 2012. Pangloss revisited: a critique of the dilution effect and the biodiversity-buffers-disease paradigm. Parasitology 139:847-863.

Rodelo-Urrego, M., García-Arenal, F., and Pagán, I. 2015. The effect of ecosystem biodiversity on virus genetic diversity depends on virus species: a study of chiltepin-infecting begomoviruses in Mexico. Virus Evol. 1: vev004.
Rodelo-Urrego, M., Pagán, I., González-Jara, P., Betancourt, M., Moreno-Letelier, A., Ayllón, M. A., Fraile, A., Piñero, D., and García-Arenal, F. 2013. Landscape heterogeneity shapes host-parasite interactions and results in apparent plant-virus codivergence. Mol. Ecol. 22: 2325-2340.

Rodríguez-Nevado, C., Montes, N., and Pagán, I. 2017. Ecological factors affecting infection risk and population genetic diversity of a novel potyvirus in its native wild ecosystem. Front. Plant Sci. 8:1958.

Rodríguez-Nevado, C., Lam, T.T.-Y., Holmes, E.C., and Pagán, I. 2018. The impact of host genetic diversity on virus evolution and emergence. Ecol. Lett. 21:253-263.

Ronquist, F., Teslenko, M., Van Der Mark, P., Ayres, D. L., Darling, A., Höhna, S., Larget, B., Liu, L., Suchard, M. A., and Huelsenbeck, J. P. 2012. MrBayes 3.2: efficient Bayesian phylogenetic inference and model choice across a large model space. Syst. Biol. 61:539-542.

Roossinck, M. J. 2012. Plant virus metagenomics: biodiversity and ecology. Annu. Rev. Genet. 46:359-369.

Roossinck, M. J. 2015. Plants, viruses and the environment: ecology and mutualism. Virology 479-480:271-277.

Roossinck, M. J., and García-Arenal, F. 2015. Ecosystem simplification, biodiversity loss and plant virus emergence. Curr. Opin. Virol. 10: 56-62.

Sacristán, S., Fraile, A., and García-Arenal, F. 2004. Population dynamics of Cucumber mosaic virus in melon crops and in weeds in central Spain. Phytopathology 94:992-998.

Schenker, N., and Gentleman, J. F. 2001. On judging the significance of differences by examining the overlap between confidence intervals. Am. Stat. 55:182-186.

Schneider, C. A., Rasband, W. S., and Eliceiri, K. W. 2012. NIH Image to ImageJ: 25 years of image analysis. Nat. Methods 9:671-675.

Seabloom, E. W., Borer, E. T., Lacroix, C., Mitchell, C. E., and Power, A. G. 2013. Richness and composition of niche-assembled viral pathogen communities. PLoS One 8:e55675.

Shukla, D. D., Ward, C. W., and Brunt, A. A. 1994. The Potyviridae. CAB International, Wallingford, UK.

Snijders, T. A. B., and Bosker, R. J. 2012. Multilevel analysis: Basic and advanced multilevel modeling, 2nd Ed. SAGE Publications, London, UK.

Stella, J. C., Rodríguez-González, P. M., Dufour, S., and Bendix, J. 2013. Riparian vegetation research in Mediterranean-climate regions: common patterns, ecological processes, and considerations for management. Hydrobiologia 719:291-315.

Stobbe, A. H., and Roossinck, M. J. 2014. Plant virus metagenomics: what we know and why we need to know more. Front. Plant Sci. 5:150.

Streicker, D. G., Fenton, A., and Pedersen, A. B. 2013. Differential sources of host species heterogeneity influence the transmission and control of multihost parasites. Ecol. Lett. 16:975-984.

Susi, H., Filloux, D., Frilander, M. J., Roumagnac, P., and Laine, A.-L. 2019. Diverse and variable virus communities in wild plant populations revealed by metagenomic tools. PeerJ 7:e6140.

Vijayan, V., López-González, S., Sánchez, F., Ponz, F., and Pagán, I. 2017. Virulence evolution of a sterilizing plant virus: tuning multiplication and resource exploitation. Virus Evol. 3:vex033.

Virgós, E. 2001. Relative value of riparian woodlands in landscapes with different forest cover for medium-sized Iberian carnivores. Biodivers. Conserv. 10:1039-1049.

Walsh, J. A., and Jenner, C. E. 2002. Turnip mosaic virus and the quest for durable resistance. Mol. Plant Pathol. 3:289-300.

Way, M. J., and Heathcote, G. D. 1966. Interactions of crop density of field beans, abundance of Aphis fabae Scop., virus incidence and aphid control by chemicals. Ann. Appl. Biol. 57:409-423.

Wilson, D. S. 1992. Complex interactions in metacommunities, with implications for biodiversity and higher levels of selection. Ecology 73: 1984-2000.

Wren, J. D., Roossinck, M. J., Nelson, R. S., Scheets, K., Palmer, M. W., and Melcher, U. 2006. Plant virus biodiversity and ecology. PLoS Biol. 4:e80.

Zheng, L., Rodoni, B. C., Gibbs, M. J., and Gibbs, A. J. 2010. A novel pair of universal primers for the detection of potyviruses. Plant Pathol. 59: 211-220. 